\title{
Lymphomatoid Granulomatosis: Rare Radiologic Presentation as a Solitary Pulmonary Mass
}

\author{
Anna Shestakova ${ }^{1 *}$, Nicolas Gallegos ${ }^{2}$, Beverly Wang ${ }^{1}$ and Bosemani Thangavijayan ${ }^{3}$ \\ ${ }^{1}$ University of California, Irvine, Department of Pathology, Irvine, California, USA \\ ${ }^{2}$ Saddleback Hospital, Laguna Hills, California, USA \\ ${ }^{3}$ University of California, Irvine, Department of Radiology, Irvine, California, USA
}

*Corresponding author: Anna Shestakova, M.D. Ph.D. Resident Physician, PGY3 Department of Pathology and Laboratory Medicine, University of California, Irvine, 101 the City Drive, Bldg.1, Rm. 3004 Orange, CA 92868, Tel: 501-590-9612;

E-mail: gshestak@uci.edu

\begin{abstract}
Background: Lymphomatoid granulomatosis (LYG) is a rare Epstein-Barr virus (EBV)-driven lymphoproliferative disease. LYG is characterized by a progressive clinical course, which virtually always involves the lungs. LYG characteristically presents as bilateral pulmonary nodules. Pathologically, it is characterized by an angiocentric and angiodestructive infiltration of atypical EBV-positive B-lymphocytes admixed with reactive T-lymphocytes. We report a case of pulmonary LYG that presented as a large mass with complete occlusion of the right main stem bronchus intermedius in an 81-year-old female.

Case: An 81-year-old female presented with shortness of breath to the emergency department. Inpatient imaging revealed bulky mediastinal lymphadenopathy with a right lower lobe collapse, shift of the cardiomediastinal silhouette, and a large right upper lung mass. Endobronchial ultrasound-guided biopsy (EBUS) revealed complete occlusion of right mainstem bronchus due to the right upper lung mass growth into the bronchus intermedius. Histopathological examination demonstrated clusters of large atypical EBV-positive B cells interspersed in a minimally polymorphous lymphocytic background, consistent with lymphomatoid granulomatosis, grade 3/3. Patient was treated with immunochemotherapy (cyclophosphamide, doxorubicin, vincristine, and prednisone - CHOP) and Rituximab (anti-CD20 antibody). At the patient's most recent follow-up, 6 months later, she was in a stable condition and her respiratory symptoms have improved.

Conclusion: Lymphomatoid granulomatosis is a rare disease that should be considered in the differential diagnosis of a radiographic evaluation of a solitary pulmonary lung mass. Since the radiographic impression might favor carcinoma as the top differential diagnosis, biopsy of the lesion is paramount to ensure the correct diagnosis. Lymphomatoid granulomatosis is usually treated with an immunochemotherapy regimen with CHOP, and/or interferon, and Rituximab.
\end{abstract}

\section{Introduction}

Lymphomatoid granulomatosis is a rare EBV-associated B cell lymphoproliferative disorder ${ }^{[1]}$. LYG virtually always involves lungs of an adult male. Its usual radiographic presentation is characterized by multiple bilateral nodular pulmonary lesions ${ }^{[2]}$.

The most common site of involvement is the lungs, followed by other extra pulmonary sites including skin and brain ${ }^{[3]}$. Recent single institution analysis of LYG demonstrated that all patients had lung involvement clinically $(100 \%)$, and positive serology for EBV infection $(100 \%)^{[4]}$. It is hypothesized that inadequate immunologic response to EBV infection is involved in the development of $\mathrm{LYG}^{[5]}$.

Histologically the LYG lesions show angiocentricity, variably polymorphous lymphocytic infiltrate, and large atypical EBV-positive B cells ${ }^{[6,7]}$. Vascular changes are prominent in LYG and show lymphocytic vasculitis with infiltration of vascular wall. Vascular integrity is often compromised that results in large areas of necrosis -- incorrectly termed "granulomatosis". It is invariably associated with EBV infection. Grading of the lesions is based on morphologic
Received date: February 21, 2019

Accepted date: March 19, 2019

Published date: March 25, 2019

Citation: Shestakova, A., et al. Lymphomatoid Granulomatosis: Rare Radiologic Presentation as a Solitary Pulmonary Mass. (2019) Intl J Cancer Oncol 6(1): 1-3.

Copyright: (C) 2019 Shestakova, A. This is an Open access article distributed under the terms of Creative Commons Attribution 4.0 International License. 
Citation: Shestakova, A., et al. Lymphomatoid Granulomatosis: Rare Radiologic Presentation as a Solitary Pulmonary Mass. (2019) Intl J Cancer Oncol 6(1): 1-3.

features and the number of EBV-positive B cells ${ }^{[6,4]}$. The varying proportion of large EBV-positive neoplastic B-cells to admixed reactive T-cells determines grading of lymphomatoid granulomatosis. It is imperative to distinguish Grade 3 from Grade 1 and 2 , since therapy is guided by the grade of $\mathrm{LYG}^{[1]}$. Grade 1 lesions contain polymorphous reactive T-lymphocytes with rare large EBV-positive neoplastic cells (less than 5 per HPF). Grade 2 lesions contain occasional clusters of large neoplastic EBV-positive cells (rarely up to 50 per HPF). Grade 3 lesions are characterized by minimally polymorphus reactive lymphocytic background with readily identifiable large atypical EBV-positive neoplastic cells. Grade 3 lesions usually show large areas of ne$\operatorname{crosis}^{[6]}$.

Rarely, LYG presents as a solitary mass in the lung ${ }^{[8-10]}$. We report a rare radiographic presentation of pulmonary lymphomatoid granulomatosis as a single mass with the obstruction of right main stem bronchus.

\section{Case Report}

An 81-year-old female presented with shortness of breath to the emergency department. CT chest with contrast revealed a large right upper lobe mass invading and occluding the right upper lobe bronchus with associated distal post obstructive complete right upper lobe collapse. There was also endobronchial invasion into the bronchus intermedius, and bulky mediastinal lymphadenopathy (Figure 1). A PET scan showed FDG avid right upper lobe mass with mediastinal invasion (Figure 2). The patient underwent endobronchial ultrasound-guided cryobiopsy (EBUS) and airway recanalization.

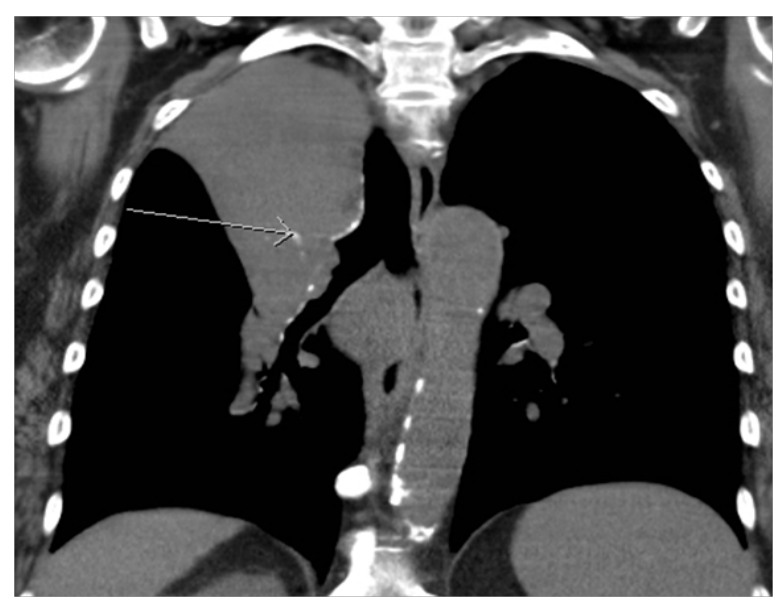

Figure 1: Non contrast CT chest showing right upper lobe mass with endobronchial invasion of right upper lobe bronchus and associated complete distal post obstructive collapse of right upper lobe.

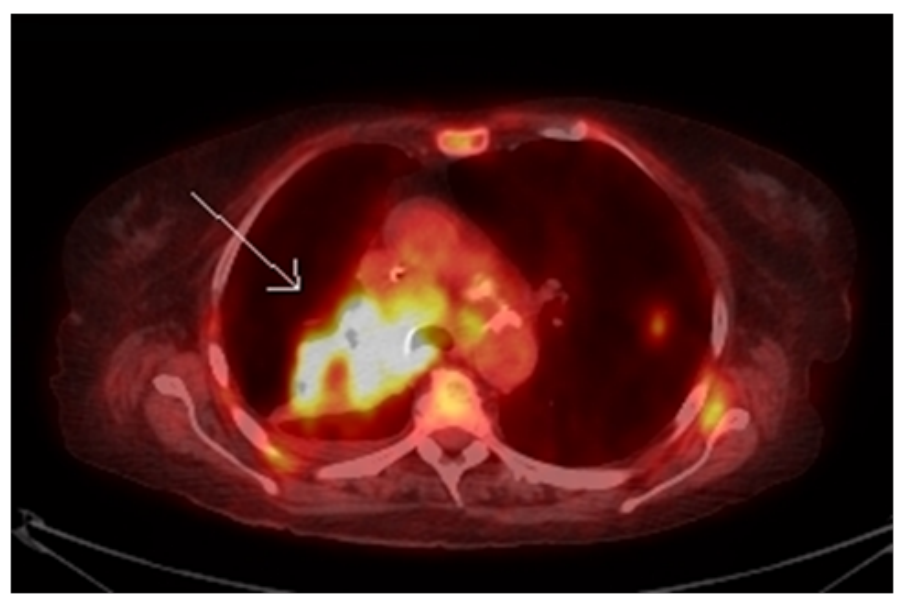

Figure 2: PET CT showing FDG avid right upper lobe mass with mediastinal invasion.

The histopathologic evaluation revealed prominent angiocentric and angiodestructive inflammatory infiltrate, composed of small lymphocytes and readily identifiable large atypical lymphocytes (Figure 3, A-B). There were large areas of necrosis. Immunohistochemical stains for CD3 highlighted numerous reactive small T-lymphocytes. Immunohistochemical stains for CD20 highlighted numerous atypical large B cells. The Ki67 expression was high, highlighting every atypical B cell. EBV EBER in situ hybridization was positive in atypical large lymphocytes. These findings are consistent with grade 3 lymphomatoid granulomatosis (Figure. 3, C-E). A CT scan was performed following the EBUS biopsy to assess the effect of recanalization.

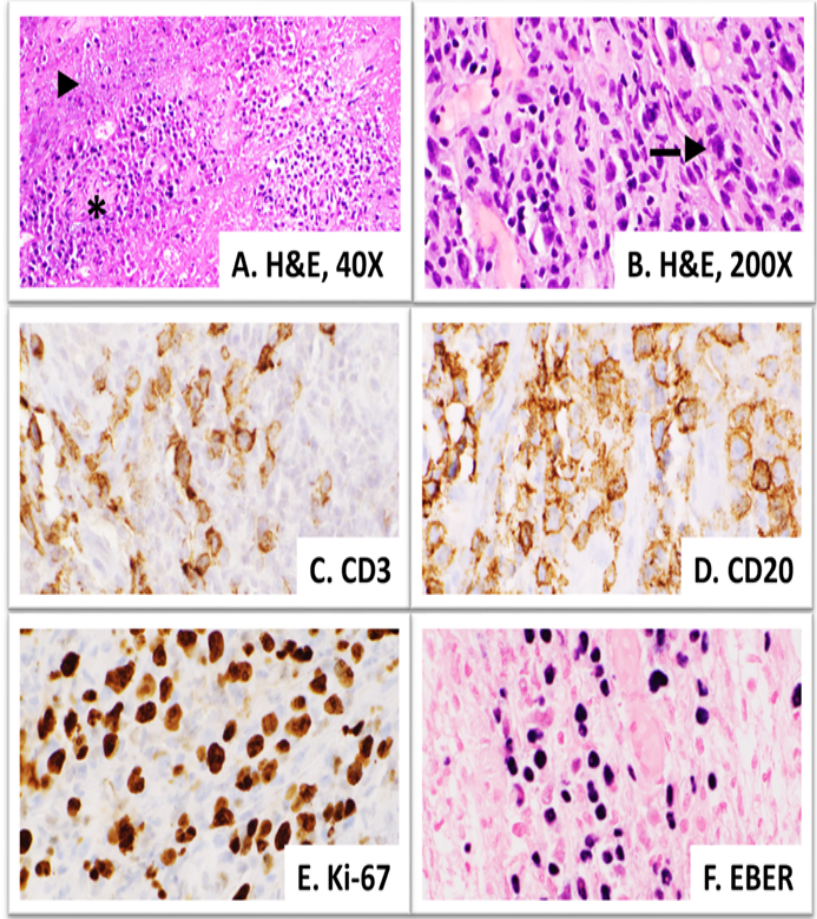

Figure 3: Lymphomatoid granulomatosis. A - Angiocentric (asterisk) polymorphous lymphoid infiltrate with large areas of necrosis (arrowhead). B. Note large atypical B cells (arrow). C - E - Immunohistochemical stains highlight admixed reactive $\mathrm{T}$ cells $(\mathrm{C})$, large neoplastic B-cells positive for CD20 (D) with increased $\mathrm{Ki}-67$ proliferation index (E). Neoplastic B-cells are positive for EBV-EBER by in situ hybridization (F). ${ }^{*}$ - vessel, $\longrightarrow$ - necrosis, $\longrightarrow$ - atypical B cells. 
The patient was treated with dose-adjusted CHOP and two doses of Rituximab, $700 \mathrm{mg}$ and $1400 \mathrm{mg}$ over two weeks. The patient was discharged 11 days after initiation of treatment. The patient is currently followed as an outpatient. No new lesions have been identified.

\section{Discussion}

LYG is a rare angiodestructive EBV-associated B-cell lymphoproliferative disorder that was first described over four decades ago $^{[11]}$. LYG invariably involves the lungs, and usually affects adult males. It is composed of large atypical EBV-positive B cells with admixed reactive $\mathrm{T}$ cells. Angiocentric distribution and lymphocytic vasculitis are common. LYG presents as a spectrum of histological grades that is determined by the number of EBV-positive B cells. Since therapy and clinical prognosis are guided by grading it is important to accurately identify the grade of LYG. Grade 1 and 2 lesions have an increasing number of EBV-positive B cells (rarely up to 50 per HPF) in a polymorphous T cell-rich lymphocytic background. Grade 3 lesions have abundant EBV-positive B cells admixed with reactive $\mathrm{T}$ cells. Importantly, a uniform population of large atypical EBV-positive B cells without a polymorphous background should be diagnosed as Diffuse Large B Cell Lymphoma, not otherwise specified (DLBCL NOS) ${ }^{[6]}$.

Radiographically LYG usually presents as bilateral pulmonary nodules ${ }^{[2]}$. Rare cases of pulmonary LYG presenting as a single mass or masquerading as a lung abscess are reported ${ }^{[12,10]}$. Grade 3 LYG lesions have large areas of necrosis that can be misleading into the radiographic diagnosis of carcinoma. Resections of unilateral masses of pulmonary LYG that were radiographically compatible with carcinoma have been reported ${ }^{[12]}$. Therefore, it is imperative to have LYG in the differential diagnosis during radiographic evaluation of a solitary lung mass. Histopathologic examination of the tissue is paramount to achieve a correct diagnosis. Since lymphocyte-rich lesions are well known to mimic carcinoma on the cytology endobronchial biopsy or transthoracic needle biopsies are preferred procedures to obtain a correct diagnosis of lymphomatoid granulomatosis.

The treatment strategy for LYG includes steroids, cyclophosphamide, and interferon alpha-2b and anti-CD20 monoclonal antibody. The clinical behavior of LYG varies, ranging from that of an indolent process to that of an aggressive large B-cell lymphoma. Generally the prognosis is poor, with up to $64 \%$ patients succumbing to the disease within the first year of diagnosis ${ }^{[13]}$. More recently, the use of chemoimmunotherapy with CHOP-Rituximab and/or interferon resulted in a 5-year overall survival of $70 \%{ }^{[7]}$.

\section{References}

1. Dunleavy, K., Roschewski, M., Wilson, W.H. Lymphomatoid granulomatosis and other Epstein-Barr virus associated lymphoproliferative processes. (2012) Curr Hematol Malig Rep 7(3): 208-215. PubMed |CrossRef |Others

2. Hare, S.S., Souza, C.A., Bain, G., et al. The radiological spectrum of pulmonary lymphoproliferative disease. (2012) Br J Radiol 85(1015): 848-864.
PubMed | CrossRef | Others

3. Katzenstein, A.L., Doxtader, E., Narendra, S. Lymphomatoid granulomatosis: insights gained over 4 decades. (2010) Am J Surg Pathol 34(12): e35-48. PubMed | CrossRef | Others

4. Song, J.Y., Pittaluga, S., Dunleavy, K., et al. Lymphomatoid granulomatosis, a single institute experience: pathologic findings and clinical correlations. (2015) Am J Surg Pathol 39(2): 141-156.

PubMed | CrossRef | Others

5. Wilson, W.H., Kingma, D.W., Raffeld, M.R. et al. Association of lymphomatoid granulomatosis with Epstein-Barr viral infection of B lymphocytes and response to interferon-alpha 2b. (1996) Blood 87(11): 4531-4537.

PubMed | CrossRef $\mid$ Others

6. "WHO Classification of Tumours of Haematopoietic and Lymphoid Tissues, Fourth Edition. (2018) WHO-OMS.

PubMed | CrossRef $\mid$ Others

7. Roschewski, M., Wilson, W.H. Lymphomatoid granulomatosis. (2012) Cancer J 18(5): 469-474.

PubMed |CrossRef |Others

8. Mohyuddin, G.R., Sultan, F., Khaleeq, G. A Rare Presentation of a Rare Disease: Pulmonary Lymphomatoid Granulomatosis. (2019) Case Rep Pulmonol 2012: 3.

PubMed | CrossRef $\mid$ Others

9. Kim, K.H., Park, J., Yoo, J.Y., et al. Low Grade Pulmonary Lymphomatoid Granulomatosis with an Endobronchial Mass. (2015) Tuberc Respir Dis (Seoul) 78(2): 137-141. PubMed | CrossRef | Others

10. McCloskey, M., Catherwood, M., McManus, D., et al. A case of lymphomatoid granulomatosis masquerading as a lung abscess. (2004) Thorax 59(9): 818-819. PubMed |CrossRef | Others

11. Liebow, A., Carrington, C.R., Friedman, P.J. Lymphomatoid granulomatosis. (1972) Hum Pathol 3(4): 457-558. PubMed | CrossRef $\mid$ Others

12. Bartosik, W., Raza, A., Kalimuthu, S., et al. Pulmonary lymphomatoid granulomatosis mimicking lung cancer. (2012) Interact Cardiovasc Thorac Surg 14(5): 662-664.

PubMed $\mid$ CrossRef $\mid$ Others

13. Katzenstein, A.L., Carrington, C.B., Liebow, A.A. Lymphomatoid granulomatosis: a clinicopathologic study of 152 cases. (1979) Cancer 43(1): 360-373.

PubMed | CrossRef | Others

Submit your manuscript to Ommega Publishers and we will help you at every step:

- We accept pre-submission inquiries

- Our selector tool helps you to find the most relevant journal

- We provide round the clock customer support

- Convenient online submission

- Thorough peer review

- Inclusion in all major indexing services

- Maximum visibility for your research

Submit your manuscript at OMMEgA Publishers

https://www.ommegaonline.org/submit-manuscript 